Article

\title{
Exploring the Potential for Just Urban Transformations in Light of Eco-Modernist Imaginaries of Sustainability
}

\author{
Pernilla Hagbert ${ }^{1, *}$, Josefin Wangel ${ }^{2}$ and Loove Broms ${ }^{3,4}$ \\ ${ }^{1}$ Department of Urban Planning and Environment, KTH Royal Institute of Technology, 10044 Stockholm, Sweden; \\ E-Mail: pernha@kth.se \\ 2 Department of Urban and Rural Development, Swedish University of Agricultural Sciences, 75651 Uppsala, Sweden; \\ E-Mail: josefin.wangel@slu.se \\ ${ }^{3}$ Department of Sustainable Development, Environmental Science and Engineering, KTH Royal Institute of Technology, \\ 10044 Stockholm, Sweden; E-Mail: loove@kth.se \\ ${ }^{4}$ Department of Design, Interior Architecture and Visual Communication, Konstfack University of Arts, Crafts and Design, \\ 12626 Stockholm, Sweden \\ * Corresponding author
}

Submitted: 31 May 2020 | Accepted: 1 September 2020 | Published: 12 November 2020

\begin{abstract}
This article approaches urban ethics through critically examining the production and reproduction of an eco-modern sociotechnical imaginary of sustainable urban development in Sweden, and the conditions and obstacles this poses for a just transformation. We see that notions of ecological modernization re-present problems of urban sustainability in ways that do not challenge the predominant regime, but rather uphold unjust power relations. More particularly, through an approach inspired by critical discourse analysis, we uncover what these problem representations entail, deconstructing what we find as three cornerstones of an eco-modern imaginary that obstruct the emergence of a more ethically-engaged understanding of urban sustainability. The first concerns which scales and system boundaries are constructed as relevant, and how this results in some modes and places of production and consumption being constructed as more efficient-and sustainable-than others. The second cornerstone has to do with what resources and ways of using them (including mediating technologies) are foregrounded and constructed as more important in relation to sustainability than others. The third cornerstone concerns the construction of subjectivities, through which some types of people and practices are put forth as more efficient-and sustainable-than others. Utilizing a critical speculative design approach, we explore a selection of alternative problem representations, and finally discuss these in relation to the possibility of affording a more ethical urban design and planning practice.
\end{abstract}

\section{Keywords}

eco-modern; efficiency; design; sustainability; urban transformation

\section{Issue}

This article is part of the issue "Built Environment, Ethics and Everyday Life" edited by Mattias Kärrholm (Lund University, Sweden) and Sandra Kopljar (Lund University, Sweden).

(C) 2020 by the authors; licensee Cogitatio (Lisbon, Portugal). This article is licensed under a Creative Commons Attribution 4.0 International License (CC BY).

\section{Introduction}

Increasing attention has been given to the political and ethical implications of sustainability transformations (Agyeman \& Evans, 2004; Avelino, Grin, Pel, \& Jhagroe, 2016; Bradley, 2009). Already the Brundtland report (WCED, 1987) pointed to the interdependencies between social and environmental systems, emphasizing that development needs to comply with planetary boundaries, as well as consider issues of social and environmental justice. What the report failed to do, however, was to discuss to what extent such a development 
is possible within the frames of a capitalist economic system. On the contrary, continued economic growth is presented as a prerequisite for sustainable development, rendering ecological modernization the only possible way forward: "It [sustainable development] requires a change in the content of growth, to make it less material and energy-intensive and more equitable in its impact" (WCED, 1987, Chapter 2, §36).

Today, more than 30 years has passed since the publication of the Brundtland report, and we now know, all too well, that ecological modernization is not sufficient. The ecology of crises (Woroniecki, 2020), including crises in ecological, social, economic, and political systems, calls for a radical transformation of society. The major societal shifts needed entail reconfiguring or completely overhauling key socio-material systems that today afford the reproduction of unsustainable modes of production and consumption (Geels, 2010; Markard, Raven, \& Truffer, 2012). This includes challenging power regimes and imaginaries of what constitutes development, for whom, and in what ways (Avelino et al., 2016; Kenis, Bono, \& Mathijs, 2016). It also includes challenging what Jasanoff (2018) describes as contradictory stories of prosperity and sustainability, calling attention to how disparities and social injustices within our unequal societies demand differentiated solutions for just transitions.

In spite of this, sustainability as a concept and practice continues to be characterized by what has been described as a "post-political condition" (Swyngedouw, 2007). For urban sustainability, the post-political condition entails a tendency to depoliticize the implications of upholding certain production and consumption flows in urban areas (Bradley, 2009; Hult, 2015). Another implication is an avoidance of questions regarding how resources are distributed in cities, something that has been a wide concern in urban research, not the least in the framing of urban justice and the production (and reproduction) of space and place (Brenner, Marcuse, \& Mayer, 2012; Fainstein, 2010; Harvey, 1973).

Previous research has underlined the need to critically examine and address the prevalent discursive structures that shape contemporary building and planning, including assumptions of continuous growth and individualized consumption (Hagbert, Mangold, \& Femenías, 2013; Næss \& Vogel, 2012). In this article, we build on this research and set out to examine the contemporary discourse and practice of sustainable urban development in Sweden, and how this upholds certain sociotechnical imaginaries over others. The article contributes to the discussion of urban ethics as an 'ethics of urban sustainability' by showing why the problem representation of urban sustainability needs to be renegotiated and suggesting ways to do so. We here approach a critical articulation of 'just urban transformations' as a re-politicized notion of urban sustainability that is not only adaptive and inclusive, but that actively seeks to reconfigure resource flows and power relations, and that in turn demands a more ethical and reflective-rather than merely compliant-engagement with sustainable urban development.

With inspiration from critical policy analysis (Bacchi, 2009) we seek to identify and characterize what problems are represented today in sustainable urban development in Sweden, often portrayed as an international forerunner in urban sustainability. We uncover what discursive and material relations these problem representations reproduce, as well as the discursive, material and lived effects this has. Findings are synthesized into three 'cornerstones' of contemporary urban sustainability. Based on these and utilizing a critical speculative design approach to illustrate the materialization of the cornerstones in everyday life, we explore a selection of alternative problem representations, and finally discuss these in relation to the possibility of affording a more ethical urban design and planning practice.

\section{Theoretical Framing}

\subsection{Socio-Technical Imaginaries}

Originating in science and technology studies, 'sociotechnical imaginaries' is a concept developed to support the analysis of how ideas of desired futures tap into the present. Jasanoff $(2015$, p. 4) defines sociotechnical imaginaries as "collectively held, institutionally stabilized, and publicly performed visions of desirable futures, animated by shared understandings of forms of social life and social order attainable through, and supportive of, advances in science and technology."

Here we expand this perspective to a socio-material understanding, thus also including urban design and other materialities not typically considered 'technology' in our analysis. As part of this, we explore how the design and use of artefacts and built living environments are part of creating and recreating sense-making not only in the present, but also in relation to visions of the future. This adds to previous research on urban futures and sociotechnical imaginaries, such as in the exploration and problematization of storylines of urban carbon governance (Tozer \& Klenk, 2018), the notion of 'smartness' (Sadowski \& Bendor, 2018), and visions of urban modernization, including the "ways in which past technologies come to shape desired urban futures" (Molden \& Meehan, 2018).

\subsection{A Socio-Material and Relational Understanding of the Built Environment}

We thus take a socio-material and relational understanding of the built environment, seeing 'the material' (e.g., technologies, infrastructures, buildings and their spatial distribution) as an expression of discourse and social and material relations. In other words, worldviews, ideals, and systems of production and consumption shape the type of materialities we develop. To understand why fossil fuels, cars, malls, and smartphones became such ubiquitous parts of modern (urban) life, it does not suffice to 
look at the technological conditions for such innovations to appear; rather, we need to consider the role they play in reproducing specific social and material relations. This takes a number of different expressions, one being that the design of urban living environments affords certain ways of being and acting in the everyday.

Murdoch (2005, p. 197) describes the need for a relational spatial understanding of what he calls "ecological actions" and the "social and spatial arrangements that will be required if such [ecological] ways of being are to be established in practice." Following a relational materialist approach, different elements of urban development need to be seen as interlinked and understood as heterogeneous, encompassing politico-economic factors and technological assumptions, as well as subjective or normative discursive perspectives. Central to our argument of urban ethics made here, we understand that what is seen as the right thing to do and the right way of doing it is a matter of cultural norms and social negotiations, adhering to or contesting established imaginaries and regimes.

Another expression of these socio-material entanglements is path-dependency (Garud, Kumaraswamy, \& Karnøe, 2010), where some ways of developing a city seem to make more sense than others because they align with existing social and material relations. This pathdependency also steers how we assess what measures in the built environment are deemed relevant or not. Ultimately, this results in a self-reinforcing bias and contributes to the formation of hegemonic stories about, for example, what constitutes 'sustainable living' and 'appropriate' development (Hagbert \& Bradley, 2017). The role of cities in relation to sustainability transformations also raises questions of contextualization, recognizing the diversity in spatial and institutional conditions and the networks, actors, and resources available in different geographies (Coenen, Benneworth, \& Truffer, 2012).

\subsection{An Ethical Approach?}

As we explore in this article, assumptions of sustainable urban development are neither a given nor neutral, but constitute a matter of ethical consideration in need of further scrutiny. Jasanoff $(2018$, p. 13$)$ points to the vulnerability of relying on science and technology to provide sustainability solutions, which tends to downplay the fact that "the problems we face are as much ethical and political." It also fails to recognize the institutional conditions and power relations implied and upheld in current socio-technical regimes (Avelino et al., 2016).

When it comes to defining what is considered just, it is moreover important to acknowledge the varying ontological understandings that frame different ethical approaches. As argued by van Staveren (2007), positivist economic assumptions of efficiency as a 'value-neutral' concept, for example, tend to reject all distributive concerns as 'normative'-leading to a common trade-off between efficiency and equity. Utilitarian and libertarian ethics (such as implied in conventional economic theories) do not necessarily result in the most efficient use of society's resources. What is measured (and sought after) is sub-optimal total utility maximization, and not minimizing resource use (van Staveren, 2007). Such suboptimized interpretations also emerge in sustainable urban development projects (Hagbert et al., 2013), with a discourse on efficiency that fails to take a more holistic perspective on what should be sustained, for whom, and what is to be developed. Critiques of a growthcentered interpretation of sustainability also challenge whether this type of economic sub-optimization can ever be compatible with the socio-ecological transformations needed (Asara, Otero, Demaria, \& Corbera, 2015).

Engaging with aspects of justice needs to furthermore consider both a distributional and procedural dimension, and take into consideration the values which underlie a given system of justice (Deutsch, 1975) and how these are reproduced in both the imaginaries created and in practice. This on one hand entails examining who bears the consequences of, versus who is ascribed responsibility for, current unsustainable practices and privileges. On the other hand, discussing what constitutes 'just' in urban transformations also means looking at who and what is assumed to change, as well as how and in what forms that change is conceived to happen.

Already in the framing of wicked problems, Rittel and Webber (1973) argued the insufficiency of a positivist rationale of planning providing top-down solutions to complex societal issues. Instead, planning needs to handle uncertainties and shifting understandings of societal problems as political and scientific paradigms change. Yet, a previously predominantly techno-centered notion of sustainability in housing and urban development has shaped the discourse for several decades (Hagbert et al., 2013; Jensen, Jørgensen, Elle, \& Lauridsen, 2012), and continues to limit the perceived scope of action (Hagbert \& Malmqvist, 2019), particularly with regards to social sustainability goals of ensuring a just distribution of power, resources, and opportunities.

For urban planning and design practices to be able to contribute to just urban transformations, we here make the point that the formulation and materialization of urban sustainability need to be renegotiated in order to acknowledge relational and ethical sensitivities. This includes addressing how to approach an ethicallyengaged practice that is reflexive and critical of its own assumptions, as well as the friction points that emerge between different interests and imaginaries (Flyvbjerg, 2004; Fridlund, 2017).

\section{Research Approach}

\subsection{Critical Discourse Analysis}

The research presented in this article is issue-driven (Robinson, 2008) and combines critical discourse analysis with speculative critical design. The critical discourse 
analysis draws on the WPR approach ("What is the problem represented to be?" see Bacchi, 2009), and is used to identify and analyze problem representations in contemporary sustainable urban development in Sweden. WPR is developed to analyze problem representations through existing policy proposals. While a WPR of urban policy-making (as exemplified in Swedish building regulations) would reveal one layer of problem representation, here we will read urban development as policyin-practice. This means that we see urban planners as part of the policy-making process, in line with what Tewdwr-Jones (2003) calls the "planning polity."

Here we take an approach inspired by critical discourse analysis, yet it should be understood primarily as an explorative, non-exhaustive reading of, and search for, the socio-technical imaginaries expressed in contemporary Swedish sustainable urban development. The reason for including socio-technical imaginaries in the WPR analysis is our hunch that the problem representations in sustainable urban development projects cannot solely be derived from existing policy-these projects tend to go beyond what is demanded to also suggest a notion of what is imagined, or in essence, planned for. The socio-technical imaginary can be identified primarily in visions guiding the development of new or refurbished areas, but also in how Swedish urban sustainable development is showcased in an international market. A Swedish 'brand' of urban sustainability is often seen as an international forerunner, and promoted to be exported all over the world, not least to China (Hult, 2015). Hence, critically examining the main claims of this development provides relevant insights not only for the Swedish planning context per se, but indirectly also as part of an increasingly global urban sustainability discourse and practice.

Looking at how the design of urban living environments is regulated, there are a number of targets, regulations, and recommendations to consider at local, regional, and national levels of governance. Sustainability programs for urban development projects typically also include their own sets of targets. In addition to this, the socio-technical imaginary can also be identified in calls for research and innovation projects aimed at supporting sustainable urban development at a national or local level, as well as those reproduced in planning conferences and professional networks. The empirical basis for the discourse analysis conducted here is a combination of primary and secondary data. The former primarily consists of our study of documents from ongoing urban development projects and urban policies in Sweden in the form of plans, programs, and municipal policy documents, while the latter primarily comes from previous research outlining discursive structures that re-emerge across cases in different geographical contexts. Through this reading of documents and previous research, we identify recurring themes that we then categorize into what we call three cornerstones of an eco-modern imaginary of urban sustainability.
Examples of projects and policies analyzed include what are considered 'showcase developments' of Swedish urban sustainability located in the three largest cities-Stockholm, Gothenburg and Malmöderived from our own and other primarily qualitative research on urban development and discourses on sustainability in these contexts (Bradley, Hult, \& Cars, 2013; Hagbert \& Femenías, 2016; Hagbert et al., 2013; Isaksson \& Heikkinen, 2018; Tahvilzadeh, Montin, \& Cullberg, 2017; Wangel, 2013). These include the developments of Hammarby Sjöstad and the Royal Seaport in Stockholm, Västra Hamnen and Hyllie in Malmö, and Kvillebäcken and the larger RiverCity development in Gothenburgrepresenting some of the largest urban development projects in Northern Europe. Yet previous research also includes case studies of mid-sized cities that tend to echo the same type of developments, albeit often with a more limited financial range (Storbjörk \& Hjerpe, 2014; Storbjörk, Hjerpe, \& Isaksson, 2018). This, in addition to previous overarching research on the prerequisites for sustainability transitions in Swedish housing development, planning, and policy (Hagbert \& Malmqvist, 2019; Isaksson \& Hagbert, 2020), provides a broad basis for our reading of imaginaries of urban sustainability in Sweden.

\subsection{Critical Speculative Design}

In order to critically examine how historical and contemporary norms have shaped urban development, as well as to re-imagine and materialize alternatives, we have used-in addition to the critical discourse analysis approach outlined above-a design-driven research methodology commonly referred to as research-throughdesign (Frayling, 1993; Seago \& Dunne, 1999). Central to a design-driven approach is the making of artefacts, through which general and abstract phenomena can be translated to the particular and everyday, and vice versa. For this article we used a specific type of design-driven research, namely critical speculative design, which is an approach in which design is used as an explorative and problem-probing tool, rather than as a tool for problemsolving (Dunne \& Raby, 2013). Through critical speculative design, traditions and ideals that have become normalized to the extent of becoming 'invisible' can be brought to the surface and called into question. Here, the development of artefacts is central, since it is by being confronted with a 'novum' that productive cognitive dissonance can be reached - what Debaise and Stengers (2017) discuss as increased friction in the present. By materializing ideals and assumptions, the design speculations act as mediators and amplifiers of these, affording critical engagement and reappraisal of ideas and relations previously taken for granted (Koskinen, Zimmerman, Binder, Redström, \& Wensveen, 2011).

For this article, we have used speculative design as a vehicle for deconstructing and reconstructing urban sustainability. To exemplify what an alternative understanding of urban sustainability could entail, we use ex- 
amples from two critical speculative design projectsSensing Energy (Broms, Wangel, \& Andersson, 2017) and Beyond Efficiency. These projects are situated in the contemporary sustainable urban development discourse in Sweden, and particularly address different urban typologies within what is understood as different conditions for transformation.

\section{Three Cornerstones of an Eco-Modern Imaginary of Urban Sustainability}

\subsection{An Eco-Modern Imaginary}

The sustainable urban development discourse in Sweden, as it comes across in our study of ongoing urban developments in major Swedish cities, underlines what previous research has identified as an institutionalization of ecological modernization ideas in Swedish policy and planning (Lidskog \& Elander, 2012; Lundqvist, 2004). Sweden here comes across as a prime example of the institutionalization of ecological modernization ideas, characterized by the promotion of efficient or 'green' technology and urban densification, and by the foregrounding of financial and market-based incentives as drivers for sustainability (Isaksson \& Heikkinen, 2018). When looking at some of the largest projects, including the Royal Seaport in Stockholm and RiverCity in Gothenburg, the imaginaries of urban sustainability are already made explicit in the early visions, and are then unfolded in the subsequent development of programs and plans, as well as in the formulation of specific policies to enable development in line with these ideas. This includes setting environmental targets but also shaping the story of urban renewal, modernization, and prosperity.

Through a critical discourse analysis approach, we can identify a number of recurring problem representations that fit within this storyline of eco-modernization. Several of these incorporate the notion of efficiency, which appears as a prevailing theme throughout different urban development and renewal projects, and in a multitude of policies. First of all, a lack of efficiency is represented as a problem in relation to the use of (urban) space, in building performance, in the way inhabitants use buildings and the urban environment, and in the planning process per se. Supported by indicators, partly to support desirable outcomes, but also to allow for benchmarking to ensure measurable and comparable outcomes and definitions, the notion of efficiency is then used to guide decision-making and investments in public and private organizations alike.

Another problem representation is the conflation of development, innovation, and commercialization, aligning governance and industry interests in the marketing of 'Swedish Sustainability' (Hult, 2015). In such 'entrepreneurial urbanism' (Franzén, Hertting, \& Thörn, 2016), the role of urban planning becomes to provide new commodities and/or increased land values, and thus construct planners and urban designers as providing ser- vices to entrepreneurs, rather than being bureaucrats or advocates (Fridlund, 2017).

Yet another problem representation relates to ideas of 'the urban' and to urbanization. 'Urbanity' is increasingly framed as central to 'sustainability,' with density (of buildings and population) being seen as key for resource efficiency, social interaction, creativity, and innovation (Glaeser, 2011). Urbanization is seen as uncontrollable and inevitable (Syssner, 2018). The UN's New Urban Agenda as well as the global Sustainable Development Goals (SDGs) further underline a deterministic assumption of urban growth. If the future is urban, and we want our future to be sustainable, then the only option is to make the urban sustainable, and conversely, sustainability must become urban-paradoxically positioning cities as both the nexus of ecological crises and as a precondition for their solutions (Brenner \& Schmid, 2015).

These problem representations are not exhaustive, in the sense that multiple other representations exist in parallel and as subsets of the ones identified here, and could be labeled and categorized in different ways. However, from the main problem representations that we see emerge both in our own empirical material and in previous research, we can further order these as a scaffold for our exploration of how an eco-modern imaginary plays out in urban sustainability. In the following, we flesh out these problem representations in the form of three cornerstones-aspects that we see as central to the upholding of certain imaginaries and practices of sustainable urban development. In relation to these cornerstones, we also present a selection of alternative problem representations, developed through critical speculative design.

\subsection{Scales and System Boundaries}

The first cornerstone concerns which scales and system boundaries are constructed as relevant, and how this results in some modes and places of production and consumption being constructed as more efficient-and sustainable-than others.

Urban sustainability is often perceived primarily as an issue of sustainability in the city, rather than of the city. This 'internal' sustainability focus implies a territorial system boundary that only considers environmental (and social) impacts that take place within the urban area-such as local emissions from cars-and disregards environmental and social ramifications of urban consumption that plays out in other places. The assumption of an available hinterland beyond city limits depends on extractivist practices located in other parts of the world, or in a national or even regional periphery. New urban districts are portrayed as eco-rational islands, disconnected from their territorial context (Brenner \& Schmid, 2015). Moreover, mainstream urban sustainability projects typically take the form of spatially delimited and project-based interventions, creating enclaves in an otherwise unchanged urban fabric. 
Besides constructing new flagship areas, sustainable urban development in Sweden today also involves transforming other, existing urban typologies through technical improvements in building performance, densification and re-branding-effectively reproducing contemporary norms of what constitutes 'sustainable' and 'urban' both materially and discursively. Neighborhoods exposed to 'renewal' projects are typically found in modernist areas that were planned with plenty of green space between the buildings, open or semi-open courtyards, and traffic separation. In light of the idea of a sustainable and proper city being characterized by a dense 'city-like' urban environment, many of these characteristics are now represented as problems, such as an inefficient use of urban space, and are blamed for driving segregation. Yet, upholding a sense of core and periphery spurs geographical inequalities between what is considered urban and what is represented as suburban or rural (Ericsson, Molina, \& Ristilammi, 2002; Jansson, 2013).

The idea of the dense city is based on the notion of optimizing systems of provision, where efficiency of scale is considered essential. Large-scale infrastructures have been very effective in providing a 'convenience revolution' (Pettersson, 2008), bringing sanitation, electricity, and communication to the masses, but it has also locked us into linear resource flows, made us dependent on fast and far-reaching mobility, and put the power over these systems and flows into the hands of just a few actors (see, e.g., Mitchell, 2011). At the same time, these large-scale infrastructures can also be seen as vulnerable to everything from system failures and external shocks, to institutional shortcomings.

One example is waste management. Today, many municipalities in Sweden have implemented systems for collecting and taking care of organic waste. With a few exceptions, these systems tend to be based on ideas of efficiency of scale. Organic waste is collected, transported to large-scale treatment facilities, and then transported off again. As illustrated in Figure 1a, the everyday interfaces of this system-i.e., where inhabitants meet and engage with the system-are reduced to inlets. This is especially the case for the increasingly popular domestic waste vacuum systems being implemented in new 'green' districts, where inhabitants do not even get to see a truck picking the waste up. The consequence of this admittedly-convenient system is that ecological and social conditions and impacts of waste management are obscured, as they happen outside the 'horizon of the everyday.' This horizon is not necessarily only a matter of geographical distance (as in far-away treatment facilities) but is also a result of panels and covers that hide local processes.

That large-scale waste management systems can be constructed to be efficient (and sustainable) is very much a matter of what system boundaries are used, what time horizons are considered, and what sustainability aspects are recognized. Juxtaposing the eco-modern idea of efficiency suggests an alternative problem representation that revolves around the super-local and smallscaled, and where resource flows are within the horizon of the everyday. Translating this to material form resulted in the compost bench (Molander, 2018; see Figure $1 \mathrm{~b}$ ), designed to resemble a radiator that can easily be moved around. The composting process serves several purposes, the most obvious being the transformation of leftovers into soil that can be used for growing new food locally. This process however also generates heat (up to $75^{\circ} \mathrm{C}$ ) - a resource that in Swedish urban areas is typically produced through incinerating waste. This design speculation thus affords a much more direct relation to waste-heating and soil for householdershelping to shift the perceived value of certain resource flows and what is considered waste.
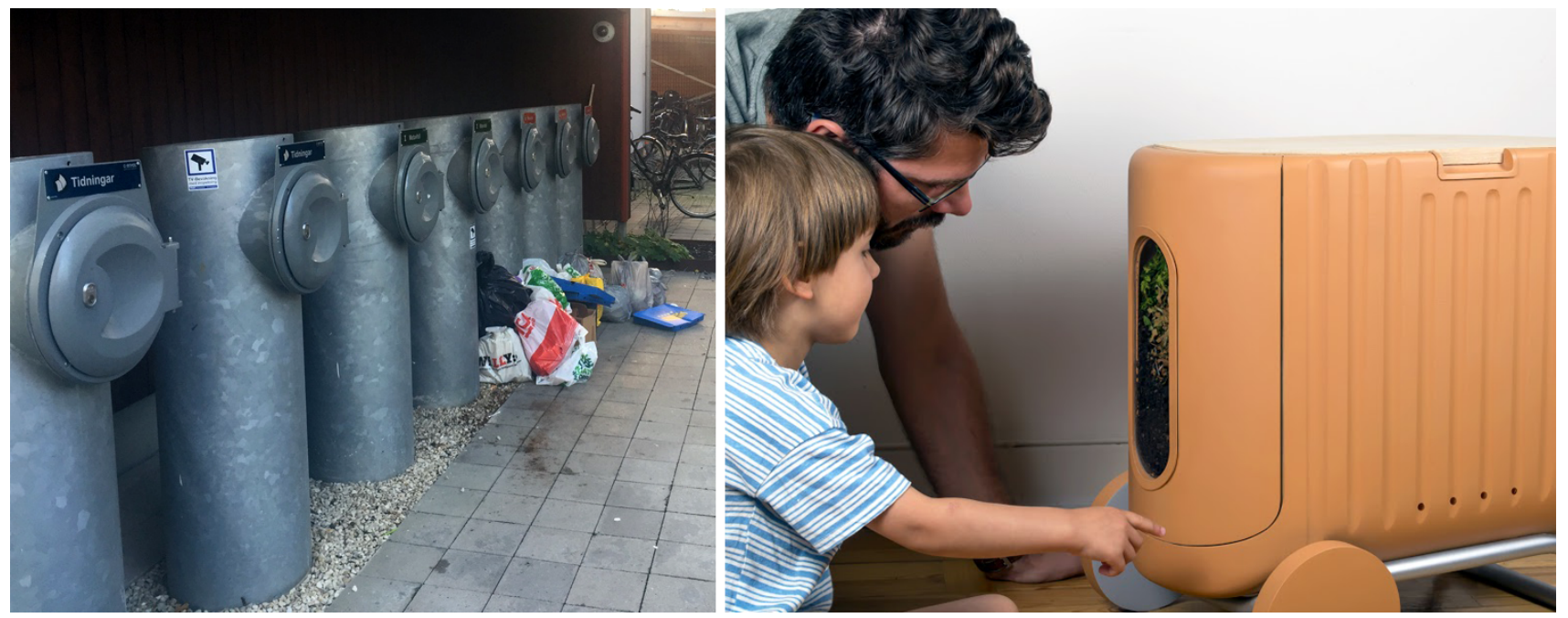

Figure 1a. A vacuum system for waste management in Kvillebäcken, Gothenburg. Photo credits: Pernilla Hagbert. 1b. Super Local Heating. Photo credits: David Molander. 


\subsection{Resources and Technologies}

The second cornerstone has to do with what resources and ways of using resources (including mediating technologies) are foregrounded and constructed as more important than others in relation to sustainability.

In sustainable urban development in Sweden, there is a clear emphasis on environmental sustainability, in the development of both new and refurbished areas. This can also be seen in how Swedish urban sustainability is showcased abroad. The foregrounding of environmental aspects can be found in targets, regulations, and recommendations for the design of living environments, as well as in sustainability programs for urban development projects, and takes place both through environmental aspects having more specific targets and indicators than social sustainability, and by being regulated through demands rather than recommendations.

The bias towards environmental sustainability can also be seen in socio-technical imaginaries identified in calls for research and innovation projects aimed at supporting sustainable urban development. Here energy and climate are framed as dominating issues, and in ways that make it possible to 'solve' them through different types of 'greentech.' Projects such as Hammarby Sjöstad and the Royal Seaport in Stockholm, Västra Hamnen in Malmö, and Kvillebäcken (as part of the larger RiverCity development) in Gothenburg, have all emphasized the integration of technological solutions, with an emphasis on low-energy and 'smart' buildings, and low-carbon mobility systems that challenge car-dependent urban development. Issues related to ecosystem services are increasingly taken into consideration, but have so far been less highlighted in the branding of new districts, and are also typically addressed through 'greentech' (as opposed to just 'green'): green roofs and other 'nature-based solutions.' The term 'green bling' or 'eco-bling' has been used in this context to signify such add-on solutions that sometimes appear more cosmetic rather than fundamentally challenging systems of provision or building concepts themselves (Liddell, 2013).

'Inefficient' behaviors are also to be addressed through technology. In the home, this means an increased number of 'smart' devices which deliver commodities with the press of a button (or even better, with no button at all-hence the smartness). An eco-modern imaginary seeks to make the machinery more efficient without questioning the socio-material fabric. If any involvement is encouraged, it is through the distributed management of technology aimed towards the 'resource man,' an incarnation of the eco-modern ideal, controlling and making optimal decisions through smart apps (Strengers, 2014).

One example of this eco-modernist understanding of resource flows and mediating technology is the approach to drinking water. As with waste, the resource flow of water lies outside the horizon of the everyday for most urban dwellers in Sweden; the origin of the water is largely unknown, as is the amount of water used and where it goes afterwards. However, in contrast to waste management, which is often considered a key issue for sustainable urban development in Sweden, water is very rarely addressed as an issue at all. The mediating technology, the tap (Figure 2a), is an archaic form undergoing only minor cosmetic changes, while the inner workings of a water-saving faucet might offer the same pressure but with lower water demand. A touchless sensor faucet further minimizes the actual engagement with the technology, while providing the same-or improved-comfort and convenience.

An alternative problem representation would be to address not the efficiency of the tap, but rather the engagement with the resource (water) altogether. One way in which this could take material form is the design speculation illustrated in Figure $2 \mathrm{~b}$. This design speculation suggests an alternative infrastructure for collecting, managing and distributing water. Both the technology of cleaning the water (filtering) and the amount of water available is clearly visible. The filtering process utilizes materials that often can be retrieved locally (such as gravel, sand, and biochar), and the collected raw water is cleaned in a two-stage process: the first fraction being suitable for household chores while the last fraction produces drinking water. Apart from problematizing the amount of water used (limiting household use to a daily ration rather than a seemingly unlimited supply), this design speculation thus also challenges the notion of using clean drinking water for all household functions, which is standard in Sweden today.

\subsection{Subjectivities}

The third cornerstone concerns the construction of subjectivities. This includes how inhabitants are addressed in sustainable urban development-including what type of agency they are and are not supposed to have-as well as what types of subject positions (primarily related to class, gender, and ethnicity) are constructed as being in line with eco-modernist ideals.

An eco-modernist understanding of sustainability foregrounds subject positions that embrace the basic tenets of this discourse: green-tech, market-based financial incentives, and an interest in 'green' consumption. The previously introduced 'resource man' (Strengers, 2014) is one such example which highlights the intersection of eco-modernism and masculinity norms (Hultman \& Pulé, 2018). In contemporary sustainable urban development in Sweden, there is a dominance of problem representations characterized by an emphasis on subject positions in which inhabitants are seen as unwilling and/or unaware in regard to changing their lifestyles to more sustainable ways of life. Thus, automation, persuasion, and nudging are needed, by means of which it is made 'easy to do the right thing.'

Looking at problem representations in relation to social sustainability shows that this is primarily represented 


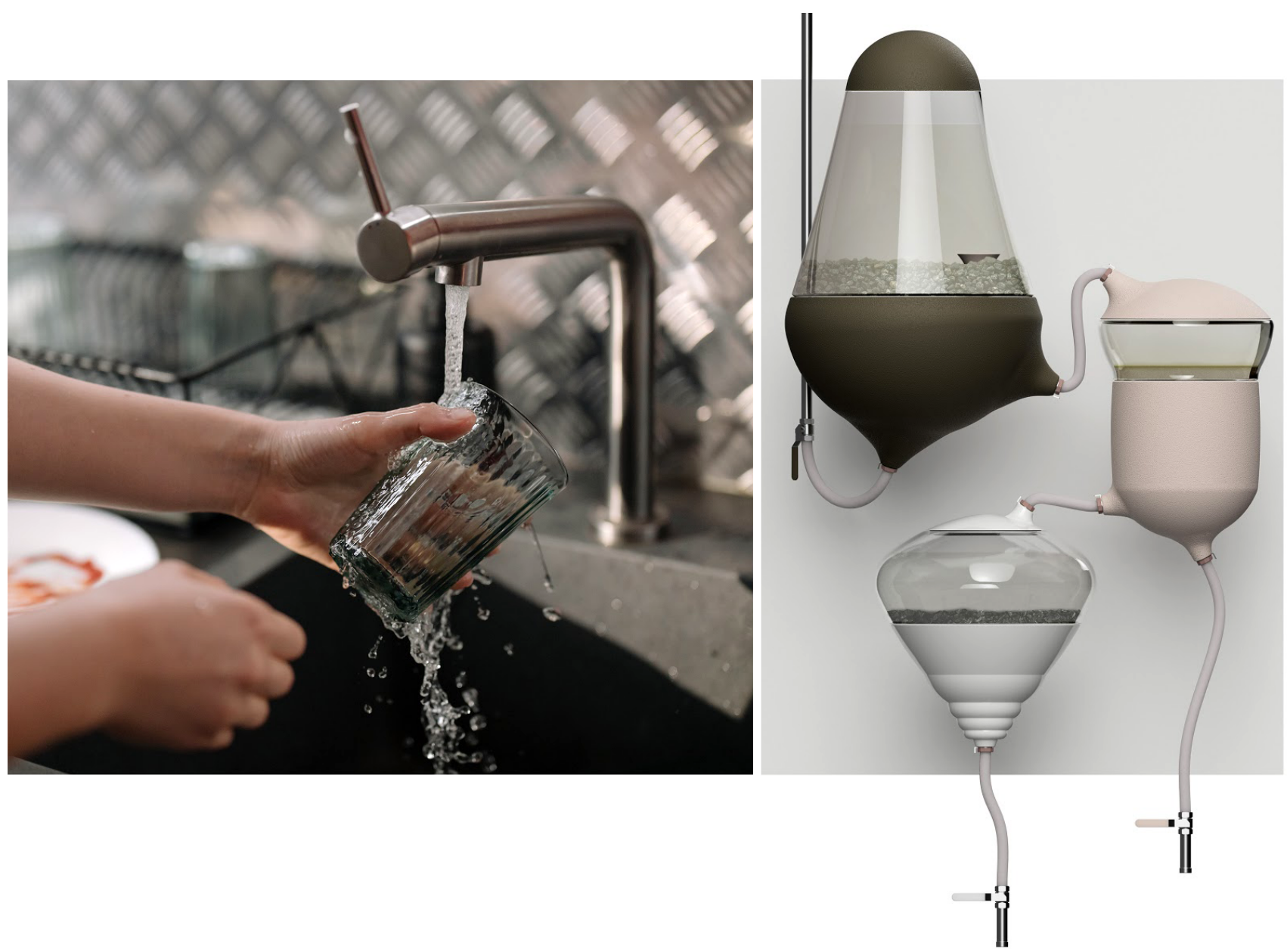

Figure 2a. The abundance of water as experienced in a conventional water tap. Image credits: cottonbro. 2b. Household Water Fraction System. Image credits: David Molander.

as matters of livability, social interaction, and attractiveness as opposed to tackling questions of justice. For example, the notion of home life portrayed in 'green' new urban districts is one of convenience and comfort, rather than addressing the human right to adequate housing or a distributive justice perspective on limiting consumption (Hagbert, 2016).

Central to both of these problem representations is the construction of an individualized subject position, for which the main agency lies in being a conscious and active consumer, expected to 'vote with one's wallet.' Together with the fact that newly built 'green' neighborhoods tend to be expensive, this means that a certain income is needed in order to occupy the subject position of a 'green' and 'conscious' consumer-effectively making the possibility to live 'sustainably' a matter of social class. However, contrary to this, several studies point to income as a key indicator of ecological footprint (Andersson, Nässén, Larsson, \& Holmberg, 2014; Newton \& Meyer, 2012).

Meanwhile, those with more limited means, and thus generally smaller footprints, are more often subject to environmental education programs, 'green' renewal projects or 'renoviction' (Gustavsson \& Elander,
2017; Mangold, Österbring, Wallbaum, Thuvander, \& Femenias, 2016). Notions of environmental awareness and being able to act in line with certain subject positions create a framing that at the same time exposes the 'other' as non-compliant (Bradley, 2009). Thus, it is not only the neighborhoods targeted in such programs that are said to be inefficient, but also their inhabitants.

The idea of the 'green,' conscious, and active consumer is a key element in upholding the eco-modern understanding of urban sustainability. Thus, by suggesting other subjectivities as legitimate, including outliers and forerunner lifestyles, the understanding of urban sustainability can also be challenged and pluralized. One example of such an alternative subject position is to replace the individualist focus with a communal one.

Taking cleanliness as example, there exists today an abundance of smart shower technologies that either limit or distribute water in different ways or encourage changed behavior through 'smart feedback' (Figure 3a). This way of making cleanliness more efficient makes a lot of sense from an eco-modernist subject position. However, an even more efficient solution (from a resource perspective) would be to have shared bathing facilities, instead of every home having their 

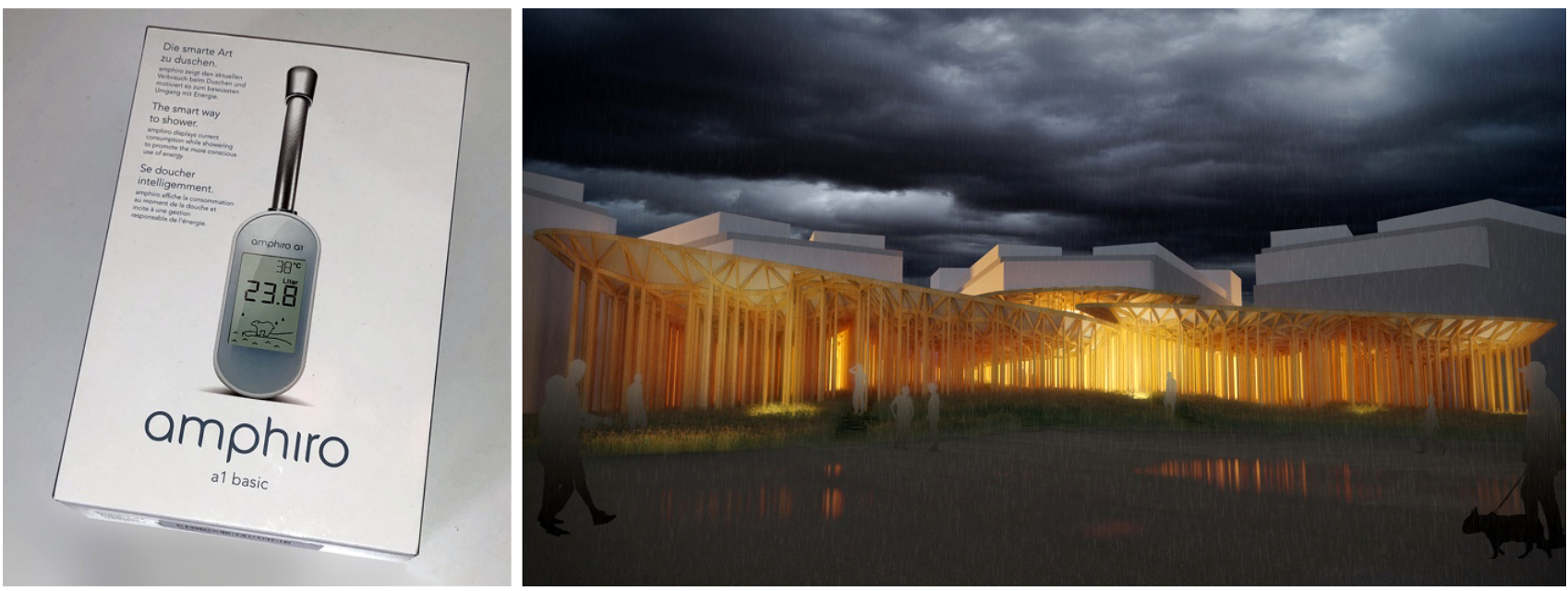

Figure 3a. A 'smart' shower application ready for an informed user. Image credits: Loove Broms. 3b. A communal bathing facility. Image credits: Patrik Rosén.

own. Emphasizing communal subject positions over individual ones, this speculative design presents a communal bath house (Figure $3 \mathrm{~b}$ ). The building caters to several rituals connecting to water and cleaning that are social rather than individualized. The structure and interiors are designed to reduce water consumption but also to enrich the experience of maintaining cleanliness.

\section{Concluding Discussion}

In this article we have explored contemporary sustainable urban development in Sweden. The analysis was carried out by identifying and examining problem representations in both policy-in-practice and in socio-technical imaginaries related to urban sustainability. Based on our analysis, we can conclude that contemporary Swedish sustainable urban development is characterized by an eco-modernist discourse-seen primarily in the promotion of 'green' technology, the reliance on market-based incentives, the emphasis on 'green' consumption, and in the foregrounding of efficiency.

That Swedish (sustainable) urban development is characterized by eco-modernism is in itself not a new finding, having been previously indicated by several scholars (Bradley, 2009; Hult, 2015; Isaksson \& Heikkinen, 2018). Apart from confirming this, our study contributes to this body of research in two ways: by fleshing out this eco-modernist discourse and its dynamics in more detail, and by suggesting ways of breaking through the impasse, both of which we believe are essential to strengthen the ability of urban planning and design practice to engage actively with issues of ethics relating to just urban transformations.

In order to flesh out the discourse and its dynamics, we identified three cornerstones-characteristics of eco-modernist representations of sustainable urban development. Looking closer at these cornerstones allowed us to see-and show-that it is neither efficiency, green technology, nor green consumption per se that char- acterizes eco-modernism, but rather the specific interpretations of what this all means-the fine print of the eco-modernist promise, so to speak. This fine print includes, for example, the construction of scales and system boundaries needed for an urban development project to come across as sustainable, and the mediating technologies that are assumed to uphold this. It also includes the construction of people as consumers rather than as citizens. Exposing this fine print and revealing the obscured and often unproblematized side of eco-modern urban sustainability is essential for the possibility of developing an urban ethics, because it allows for de-stabilizing the false consciousness of what sustainable urban development is-and what it could and should be.

Taking a critical approach to the mainstream sustainability discourse in urban development is essential if we are to acknowledge the ethical implications of urban planning and design in socio-material transformations. An eco-modern understanding of efficiency is often portrayed as a 'value-neutral' concept, where distributive concerns are dismissed as 'normative.' The question is what type of ethics (or lack thereof) an eco-modern framing then brings. What is implied is often a relative improvement-more efficient than what?-rather than an absolute understanding of what would define a 'sustainable' system. There is a need for a re-politicized notion of urban sustainability that goes beyond simply adapting to current system logics or 'including' perspectives that are currently excluded without really challenging current power hierarchies (what Arnstein, 1969, described as the lower rungs of the ladder of participation). A just urban transformation instead entails completely reconfiguring power relations, which demands an active ethical debate and continuous reflexive engagement among planners and urban designers, beyond mere compliancy with certifications and established norms.

To shed even further light on the dynamics of the ecomodernist discourse and practice, we juxtaposed eco- 
modernist 'solutions' within the three cornerstones with a selection of critical speculative design explorations. These design speculations also serve another aim: to reveal the scope of action available should 'urban sustainability' be re-negotiated. They point toward the need to envision new imaginaries that break with preconceived socio-material conditions and sub-optimizations, in order to afford new ways of being and doing.

Engaging in just transformations as an urban ethics thus also includes recognizing the competences and knowledge claims being foregrounded, and seeing which actors and issues are or are not allowed at the table. We here wish to make the point that unless we engage in a fundamental discussion about how we conceive a sustainable future society and the role of cities in this, efficiency measures will continue to take the present situation as their starting point, rather than where we 'ought to' or 'want to' be going. We recognize that this is only a rough first analysis, revealing the discourse on urban sustainability as it plays out in relation to the identified problem representations, and that further researchand developments in professional practice-are needed. Particularly when addressing the power dynamics behind the identified discourses, we see the need for an expanded debate on the ethical considerations of all actors involved in order to inform a situated engagement with a critical analysis of the assumptions and objectives in sustainable urban development.

Eventually, this all comes down to the urban planning and design practice. But rather than blaming the practice or practitioners per se, we need to understand what conditions there are for urban planning and design to engage in (more) just and sustainable urban transformations. While a false consciousness regarding urban sustainability can certainly be found amongst urban practitioners, there are also many practitioners who are well aware of the shortcomings of their practice and who are actively looking for ways to interrupt the reproduction of (eco)modernist socio-material relations. To support the development of an urban ethics, both as a sociotechnical imaginary and planning polity, we need to identify where and how this false consciousness has become institutionalized. This includes critically examining what interests and power structures shape the material practice, upholding the eco-modern myth of progress and efficiency, and thus stand in the way of an urban ethics that can approach distributive justice and differentiated solutions to just transformations.

\section{Acknowledgments}

The authors would like to thank the Swedish Energy Agency for funding this research. Furthermore, we are grateful for the insightful comments provided by the anonymous reviewers, as these comments have contributed greatly to the development of the article's main arguments. Lastly, we would like to thank our colleagues within the projects from which this article stems, who have contributed in different ways to the critical discussion and design research put forward here: Camilla Andersson, Karin Ehrnberger, David Molander, and Jonas Runberger.

\section{Conflict of Interests}

The authors declare no conflict of interests.

\section{References}

Agyeman, J., \& Evans, B. (2004). 'Just sustainability'The emerging discourse of environmental justice in Britain? The Geographical Journal, 170(2), 155-164.

Andersson, D., Nässén, J., Larsson, J., \& Holmberg, J. (2014). Greenhouse gas emissions and subjective well-being: An analysis of Swedish households. Ecological Economics, 102, 75-82.

Arnstein, S. (1969). A ladder of citizen participation. Journal of the American Planning Association, 35(4), 216-224.

Asara, V., Otero, I., Demaria, F., \& Corbera, E. (2015). Socially sustainable degrowth as a social-ecological transformation: Repoliticizing sustainability. Sustainability Science, 10(3), 375-384.

Avelino, F., Grin, J., Pel, B., \& Jhagroe, S. (2016). The politics of sustainability transitions. Journal of Environmental Policy \& Planning, 18(5), 557-567.

Bacchi, C. (2009). Analysing policy: What's the problem represented to be? Frenchs Forest: Pearson Australia.

Bradley, K. (2009). Just environments: Politicising sustainable urban development (Unpublished Doctoral dissertation). KTH Royal Institute of Technology, Stockholm, Sweden.

Bradley, K., Hult, A., \& Cars, G. (2013). From ecomodernizing to political ecologizing: Future challenges for the green capital. In J. Metzger \& A. Rader Olsson (Eds.), Sustainable Stockholm: Exploring urban sustainability in Europe's greenest city (pp. 168-194). London: Routledge.

Brenner, N., \& Schmid, C. (2015). Towards a new epistemology of the urban? City, 19(2/3), 151-182.

Brenner, N., Marcuse, P., \& Mayer, M. (Eds.). (2012). Cities for people, not for profit. Critical urban theory and the right to the city. London \& New York, NY: Routledge.

Broms, L., Wangel, J., \& Andersson, C. (2017). Sensing energy: Forming stories through speculative design artefacts. Energy Research \& Social Science, 31(Supplement C), 194-204.

Coenen, L., Benneworth, P., \& Truffer, B. (2012). Toward a spatial perspective on sustainability transitions. $R e$ search Policy, 41(6), 968-979.

Debaise, D., \& Stengers, I. (2017). The insistence of possibles: Towards a speculative pragmatism. PARSE, 7, 13-19.

Deutsch, M. (1975). Equity, equality, and need: What determines which value will be used as the basis of 
distributive justice? Journal of Social Issues, 31(3), 137-149.

Dunne, A., \& Raby, F. (2013). Speculative everything: Design, fiction, and social dreaming. Cambrdige, MA: The MIT Press.

Ericsson, U., Molina, I., \& Ristilammi, P.-M. (2002). Miljonprogram och media: Föreställningar om människor och förorter [The million program and media: Perceptions of people and suburbs]. Stockholm: Riksantikvarieämbetet \& Integrationsverket.

Fainstein, S. (2010). The just city. Ithaca, NY: Cornell University Press.

Flyvbjerg, B. (2004). Phronetic planning research: Theoretical and methodological reflections. Planning Theory \& Practice, 5(3), 283-306.

Franzén, M., Hertting, N., \& Thörn, C. (2016). Stad till salu: Entreprenörsurbanismen och det offentliga rummets värde [City for sale: Entrepreneurial urbanism and the value of public space]. Gothenburg: Daidalos.

Frayling, C. (1993). Research in art and design. London: Royal College of Art.

Fridlund, G. (2017). Utan tvivel är en inte klok: En studie om personliga skavningar som resurs för praktisk klokhet inom svensk kommunal planering [Without doubt you are not wise: A study of personal frictions as a resource for practical wisdom in Swedish municipal planning] (Unpublished Doctoral dissertation). KTH Royal Institute of Technology, Stockholm, Sweden.

Garud, R., Kumaraswamy, A., \& Karnøe, P. (2010). Path dependence or path Creation? Journal of Management Studies, 47, 760-774.

Geels, F. W. (2010). Ontologies, socio-technical transitions (to sustainability), and the multi-level perspective. Research Policy, 39(4), 495-510.

Glaeser, E. (2011). Triumph of the city: How our greatest invention makes us richer, smarter, greener, healthier, and happier. New York, NY: Penguin.

Gustavsson, E., \& Elander, I. (2017). Behaving clean without having to think green? Local eco-technological and dialogue-based, low-carbon projects in Sweden. Journal of Urban Technology, 24(1), 93-116.

Hagbert, P. (2016). A sustainable home? Reconceptualizing home in a low-impact society (Unpublished Doctoral dissertation). Chalmers University of Technology, Gothenburg, Sweden.

Hagbert, P., \& Bradley, K. (2017). Transitions on the home front: A story of sustainable living beyond eco-efficiency. Energy Research \& Social Science, 31(Supplement C), 240-248.

Hagbert, P., \& Femenías, P. (2016). Sustainable homes, or simply energy-efficient buildings? Journal of Housing and the Built Environment, 31(1), 1-17.

Hagbert, P., \& Malmqvist, T. (2019). Actors in transition: Shifting roles in Swedish sustainable housing development. Journal of Housing and the Built Environment, 34(3), 697-714.

Hagbert, P., Mangold, M., \& Femenías, P. (2013). Para- doxes and possibilities for a 'green' housing sector: A Swedish case. Sustainability, 5(5), 2018-2035.

Harvey, D. (1973). Social justice and the city. Athens, GA: University of Georgia Press.

Hult, A. (2015). The circulation of Swedish urban sustainability practices: To China and back. Environment and Planning A, 47(3), 537-553.

Hultman, M., \& Pulé, P. M. (2018). Ecological masculinities: Theoretical foundations and practical guidance. New York, NY: Routledge.

Isaksson, K., \& Hagbert, P. (2020). Institutional capacity to integrate 'radical' perspectives on sustainability in small municipalities: experiences from Sweden. Environmental Innovation and Societal Transitions, 36, 83-93.

Isaksson, K., \& Heikkinen, S. (2018). Sustainability transitions at the frontline. Lock-in and potential for change in the local planning arena. Sustainability, 10(3). https://doi.org/10.1016/j.respol.2012.02.013

Jansson, A. (2013). The hegemony of the urban/rural divide: cultural transformations and mediatized moral geographies in Sweden. Space and Culture, 16(1), 88-103.

Jasanoff, S. (2015). Future imperfect: Science, technology, and the imaginations of modernity. In S. Jasanoff \& S.-H. Kim (Eds.), Dreamscapes of modernity: Sociotechnical imaginaries and the fabrication of power (pp. 1-33). Chicago, IL: University of Chicago Press.

Jasanoff, S. (2018). Just transitions: A humble approach to global energy futures. Energy Research \& Social Science, 35, 11-14.

Jensen, J. O., Jørgensen, M. S., Elle, M., \& Lauridsen, E. H. (2012). Has social sustainability left the building? The recent conceptualization of "sustainability" in Danish buildings. Sustainability: Science, Practice, \& Policy, 8(1), 94-105.

Kenis, A., Bono, F., \& Mathijs, E. (2016). Unravelling the (post-)political in transition management: Interrogating pathways towards sustainable change. Journal of Environmental Policy \& Planning, 18(5), 568-584.

Koskinen, I., Zimmerman, J., Binder, T., Redström, J., \& Wensveen, S. (2011). Design research through practice: From the lab, field, and showroom. Waltham, MA: Morgan Kaufmann.

Liddell, H. (2013). Eco-minimalism: The antidote to ecobling (2nd ed.). London: RIBA Publishing.

Lidskog, R., \& Elander, I. (2012). Ecological modernization in practice? The case of sustainable development in Sweden. Journal of Environmental Policy \& Planning, 14(4), 411-427.

Lundqvist, L. J. (2004). 'Greening the people's home': The formative power of sustainable development discourse in Swedish housing. Urban Studies, 41(7), 1283-1301.

Mangold, M., Österbring, M., Wallbaum, H., Thuvander, L., \& Femenias, P. (2016). Socio-economic impact of renovation and energy retrofitting of the Gothenburg 
building stock. Energy and Buildings, 123, 41-49.

Markard, J., Raven, R., \& Truffer, B. (2012). Sustainability transitions: An emerging field of research and its prospects. Research Policy, 41(6), 955-967.

Mitchell, T. (2011). Carbon democracy: Political power in the age of oil. London: Verso.

Molden, O. C., \& Meehan, K. (2018). Sociotechnical imaginaries of urban development: Social movements around "traditional" water infrastructure in the Kathmandu Valley. Urban Geography, 39(5), 763-782.

Murdoch, J. (2005). Post-structuralist geography: a guide to relational space. London: Sage.

Næss, P., \& Vogel, N. (2012). Sustainable urban development and the multi-level transition perspective. Environmental Innovation and Societal Transitions, 4, 36-50.

Newton, P., \& Meyer, D. (2012). The determinants of urban resource consumption. Environment and Behavior, 44(1), 107-135.

Pettersson, R. (Ed.). (2008). Bekvämlighetsrevolutionen: Stockholmshushållen och miljön under 150 år och $i$ framtiden [The convenience revolution: Stockholm households and the environment over 150 years and in the future]. Stockholm: Stockholmia.

Rittel, H. W. J., \& Webber, M. M. (1973). Dilemmas in a general theory of planning. Policy Sciences, 4(2), 155-169.

Robinson, J. (2008). Being undisciplined: Transgressions and intersections in academia and beyond. Futures, 40(1), 70-86.

Sadowski, J., \& Bendor, R. (2018). Selling smartness: Corporate narratives and the smart city as a sociotechnical imaginary. Science, Technology, \& Human Values, 44(3), 540-563.

Seago, A., \& Dunne, A. (1999). New methodologies in art and design research: The object as discourse. Design Issues, 15(2), 11-17.

Storbjörk, S., \& Hjerpe, M. (2014). "Sometimes climate adaptation is politically correct": A case study of planners and politicians negotiating climate adaptation in waterfront spatial planning. European Planning Studies, 22(11), 2268-2286.
Storbjörk, S., Hjerpe, M., \& Isaksson, K. (2018). 'We cannot be at the forefront, changing society': Exploring how Swedish property developers respond to climate change in urban planning. Journal of Environmental Policy \& Planning, 20(1), 81-95.

Strengers, Y. (2014). Smart energy in everyday life: Are you designing for resource man? Interactions, 21(4), 24-31.

Swyngedouw, E. (2007). Impossible 'sustainability' and the postpolitical condition. In R. Krueger \& D. Gibbs (Eds.), The sustainable development paradox: Urban political economy in the United States and Europe (pp. 13-40). New York, NY: Guilford Press.

Syssner, J. (Ed.). (2018). Nya visioner för landsbygden [New visions for the countryside]. Boxholm: Linnefors förlag.

Tahvilzadeh, N., Montin, S., \& Cullberg, M. (2017). Functions of sustainability: Exploring what urban sustainability policy discourse "does" in the Gothenburg Metropolitan Area. Local Environment, 22, 66-85.

Tewdwr-Jones, M. (2003). The planning polity: Planning, government, and the policy process. Abingdon-onThames: Taylor \& Francis.

Tozer, L., \& Klenk, N. (2018). Discourses of carbon neutrality and imaginaries of urban futures. Energy Research \& Social Science, 35, 174-181.

van Staveren, I. P. (2007). The ethics of efficiency (ISS Working Paper No. 1756-2031). The Hague: ISS Group 3-Human Resources and Local Development. Retrieved from http://hdl.handle.net/1765/30712

Wangel, J. (2013). Hur hållbara är Hammarby sjöstad och Norra Djurgårdstaden? [How sustainable are Hammarby sjöstad and the Royal seaport?] In H. Teleman, C. Caldenby, E. Ullstad, \& F. von Platen (Eds.), Hållbarhetens villkor [The conditions of sustainability] (pp. 86-103). Malmö: Arena.

WCED. (1987). Our common future. New York, NY: Oxford University Press.

Woroniecki, S. (2020). Confronting the ecology of crisis: The interlinked roles of ecosystem-based adaptation and empowerment (Unpublished Doctoral dissertation). Lund University, Sweden.

\section{About the Authors}

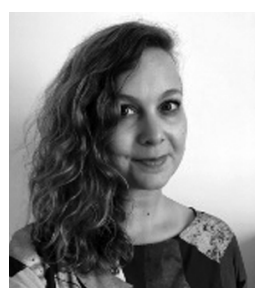

Pernilla Hagbert holds a PhD in Architecture and currently works as a researcher in Urban and Regional Studies at the Department of Urban Planning and Environment at KTH Royal Institute of Technology. Pernilla's research critically examines interpretations (and paradoxes) of sustainability in housing and urban development, and explores norm-critical, alternative ways of doing and living as part of transitions to a low-impact society.

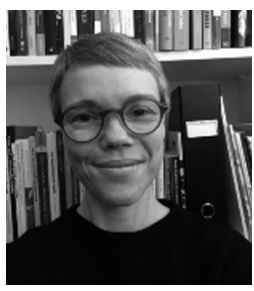

Josefin Wangel is an undisciplined researcher based at the Department of Urban and Rural Development at the Swedish University of Agricultural Sciences (SLU). Her current research focuses on urban sustainability, which she explores through an eclectic mix of discourse analysis, critical speculation, and political frustration. Josefin holds a PhD in Planning and Decision Analysis and has a background in Environmental Sciences. 
Loove Broms is an interaction designer, educator and researcher. He has a PhD in Interaction Design and holds a position as associate professor in interaction design at Konstfack, and as a researcher at KTH. Loove does research in design and sustainability with a particular interest in discursive artefacts, narratives and meaning-making. Using an experimental design research approach, the intention is to problematize present consumer culture and urban development through speculative and critical design. 